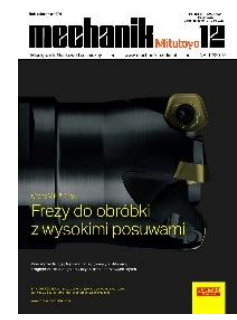

How to cite this article:

Authors: Marta B. Krawczyk, Marcin A. Królikowski, Krzysztof Filipowicz, Daniel Grochała

Title of article: "Effect of cutting parameters on geometrical surface structure of SLM manufactured CoCr alloy after face turning"

Mechanik, No. 12 (2019)

DOI: https://doi.org/10.17814/mechanik.2019.12.114

\title{
Effect of cutting parameters on geometrical surface structure of SLM manufactured CoCr alloy after face turning
}

\author{
MARTA B. KRAWCZYK \\ MARCIN A. KRÓLIKOWSKI \\ KRZYSZTOF FILIPOWICZ \\ DANIEL GROCHAŁA *
}

Dr inż. Marta B. Krawczyk, marta.krawczyk@zut.edu.pl, https://orcid.org/0000-0001-8854-5758 - Katedra Technologii Wytwarzania Wydział Inżynierii Mechanicznej i Mechatroniki, Zachodniopomorski Uniwersytet Technologiczny, Szczecin, Polska

Dr inż. Marcin A. Królikowski, marcin.krolikowski@zut.edu.pl, https://orcid.org/0000-0002-3668-8463 - Katedra Technologii Wytwarzania, Wydział Inżynierii Mechanicznej i Mechatroniki, Zachodniopomorski Uniwersytet Technologiczny, Szczecin, Polska

Dr inż. Krzysztof Filipowicz, krzysztof.filipowicz@zut.edu.pl, https://orcid.org/0000-0003-4839-2202 - Katedra Technologii Wytwarzania, Wydział Inżynierii Mechanicznej i Mechatroniki, Zachodniopomorski Uniwersytet Technologiczny, Szczecin, Polska

Dr inż. Daniel Grochała, daniel.grochala@zut.edu.pl, https://orcid.org/0000-0003-2553-7739 - Katedra Technologii Wytwarzania,

Wydział Inżynierii Mechanicznej i Mechatroniki, Zachodniopomorski Uniwersytet Technologiczny, Szczecin, Polska

Research on effect of machining parameters on geometrical surface structure of SLM manufactured CoCr alloy shafts after face turning is presented in the paper. Machining parameters were selected in order to obtain continuous variation of cutting speed at fixed feed ratio for given cutting depth. In consequent steps feed ratio was changed at fixed, unchanged cutting depth. As a criteria of optimal machining parameters, selected surface geometry parameters were measured. Experimental research was carried out by turning with typical tool and commercial cutting inserts

KEYWORDS: geometrical surface structure, chrome-cobalt alloy, SLM, face turning

\section{Introduction}

Additive manufacturing of metals - so strongly emphasized in the idea of the fourth industrial revolution forces the adaptation of classic technologies to obtain products of competitive quality [2]. This also happens with elements manufactured by additive methods from hard-to-machine alloys, which include chromium and cobalt alloys, used mainly in medicine $[1,3,4]$. Due to the high resistance to abrasive wear, complete knee and hip implants are produced from cobalt-chromium materials [5, 6]. Cobalt-chromium alloys are resistant to corrosion, creep and have a strong tendency to strengthen deformation, which along with poor thermal conductivity, high strength, and hardness, results in their poor machinability [5, 7-9]. CoCr machining is commonly associated with short tool life and low surface quality, and therefore low productivity and high manufacturing costs [5-7].

Nowadays, more and more accurate dimensions and shapes of manufactured parts are expected, therefore in mechanical engineering, elements obtained by additive manufacturing methods of metals almost always have to undergo finishing treatment. This can be material removal machining, especially cutting, performed on efficient machining centers. However, with small tolerances (V-VI class, IT), the surface condition should be taken into account. Dimensions of parts can change significantly after taking into account the roughness and specific machining properties of the CoCr alloy (in sintered or cast form). Understanding these specific properties and developing optimal technological parameters for machining in order to meet the criteria of surface quality and dimensional and shape accuracy was the subject of the research.

\section{Experimental research}

The test samples were made of cobalt-chromium alloy (ASTM F75) using the additive manufacturing technique, which is selective laser melting (SLM). The process was carried out on a REALIZER II 250 (MTT-Group) 
device equipped with a $100 \mathrm{~W}$ Nd: YAG laser. Many samples were prepared with a diameter of $\varnothing 15 \mathrm{~mm}$ and a height of $30 \mathrm{~mm}$. SLM process parameters are summarized in tab. I.

Cylindrical samples were subjected to face turning on an AFM TAE 35 machine. CNMG 1204 08-SMR 1105 inserts from Sandvik with PVD (Ti, Al) N2 coating, intended for difficult-to-cut materials, were used. Machining was carried out at constant parameters: cutting speed $V c=60 \mathrm{~m} / \mathrm{min}$; rotational speed $n=1250 \mathrm{~min}^{-1}$ and cutting depth $a p=0.5 \mathrm{~mm}$, while for feed rate $f n$, the following values were adopted: 0.1 (P1); 0.15 (P2); 0.20 (P3); 0.25 (P4); $0.40 \mathrm{~mm} / \mathrm{rev}$ (P5). The initial sample after the SLM process was designated P0. A new plate was fitted for each treatment.

TABLE I. SLM process parameters

\begin{tabular}{|l|c|}
\hline Laser power $P[\mathrm{~W}]$ & 100 \\
\hline Scan speed $V[\mathrm{~mm} / \mathrm{s}]$ & 600 \\
\hline Distance between laser paths $h[\mathrm{~mm}]$ & 0.12 \\
\hline Layer thickness $d[\mathrm{~mm}]$ & 0.03 \\
\hline Volume energy density $\varepsilon\left[\mathrm{J} / \mathrm{mm}^{3}\right]$ & 99.21 \\
\hline
\end{tabular}

\section{Examination of the geometric structure of the sample surface}

For the surface of samples after the turning process, selected parameters of the surface geometric structure (SGS) were determined with application of the AltiSurf A520 machine, equipped with a CL2 chromatic confocal sensor with the working range up to $400 \mu \mathrm{m}$ and resolution in the optical axis of the device $8 \mathrm{~nm}$. Measurements were made at measurement fields $2.0 \times 5.0 \mathrm{~mm}$ along the radius of tested rollers. The scanning resolution was set at: along $X$-axis $-0.47 \mu \mathrm{m}$, along $Y$-axis $-1.97 \mu \mathrm{m}$; this gave almost 110 million mapping points for each surface.

Digital processing of the collected point cloud and determination of the stereometric values of SGS parameters [10] were carried out using AltiMap PREMIUM 6.2 software. The collected point cloud (mean a plane, approximated by the least squares method) was leveled for each surface scan. Due to the high roughness of the sample after the SLM process, incorrectly collected points appeared during scanning of the surface (double reflections in "lenses" or kinks at the edges). To remove them, the threshold values of the collected signal were adopted at the level of $0.05 \div 99.95 \%$ (removed points were set as unmeasured values). Finally, the values of parameters describing the surface height: $S a$ and $S q$, parameters of the load-bearing capacity curve: $S k, S p k$, $S v k$, and parameters characterizing the roughness profile: $R a$ and $R z$ were determined [11]. The results are presented in figs. 1-6. In tab. II, the SGS parameters obtained for the initial sample (P0) are summarized.

TABLE II. Summary of selected SGS parameters obtained for CoCr sample after the SLM process

\begin{tabular}{|l|c|c|c|c|c|c|}
\hline Parameter & $S a[\mu \mathrm{m}]$ & \multicolumn{2}{|c|}{$S q[\mu \mathrm{m}]$} & \multicolumn{2}{c|}{$S k[\mu \mathrm{m}]$} & \multicolumn{2}{c|}{$S p k[\mu \mathrm{m}]$} & \multicolumn{2}{c|}{$S v k[\mu \mathrm{m}]$} \\
\hline P0 & 33.0 & \multicolumn{2}{|c|}{46.2} & \multicolumn{2}{c|}{68.2} & \multicolumn{2}{|c|}{19.4} & 109 \\
\hline Parameter & $S r_{1}[\%]$ & $S r_{2}[\%]$ & $\begin{array}{c}V_{\mathrm{m}} \\
{\left[\mathrm{mm}^{3} / \mathrm{mm}^{2}\right]}\end{array}$ & $\begin{array}{c}V_{\mathrm{v}} \\
{\left[\mathrm{mm}^{3} / \mathrm{mm}^{2}\right]}\end{array}$ & $R a[\mu \mathrm{m}]$ & $R z[\mu \mathrm{m}]$ \\
\hline P0 & 5.39 & 82.2 & 0.00123 & 0.0444 & 28.0 & 181 \\
\hline
\end{tabular}

Based on the analysis of results presented in fig. 1, it can be seen that as the machining parameters (feed rate) increase, the $S a$ and $S q$ parameters increase as well. The largest increase in these parameters is for the sample with the highest feed rate. However, compared to the initial surface, the results obtained are even 46 times lower.

Fig. 2 shows the values of the load capacity curve $S k$, $S p k$, and $S v k$. It is noticeable that the upward trend of SGS parameters is maintained along with the increase in feed rate. Considering the values of the parameter Svk which is responsible for the retention of oil, grease and dirt on the surface - for P5, it is almost 8.5 times higher than for P1 and more than 10 times lower compared to P0. 


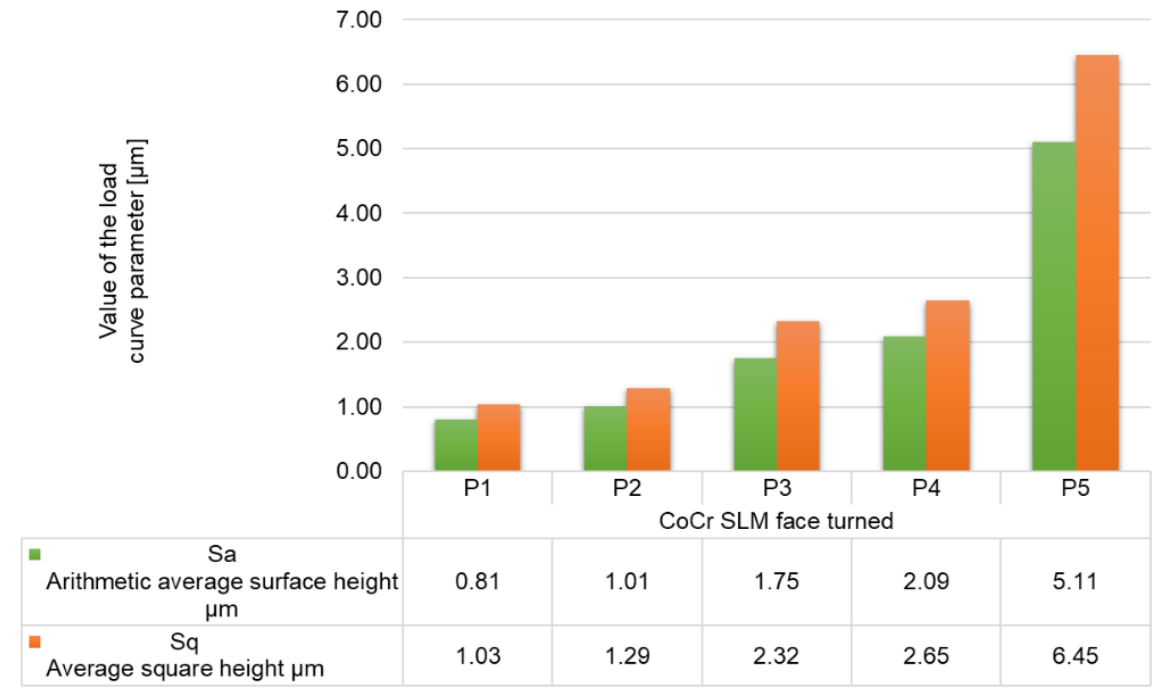

Fig. 1. Values of altitude parameters SGS ( $S a$ and $S q$ ) obtained after face turning of CoCr materials produced by the SLM method

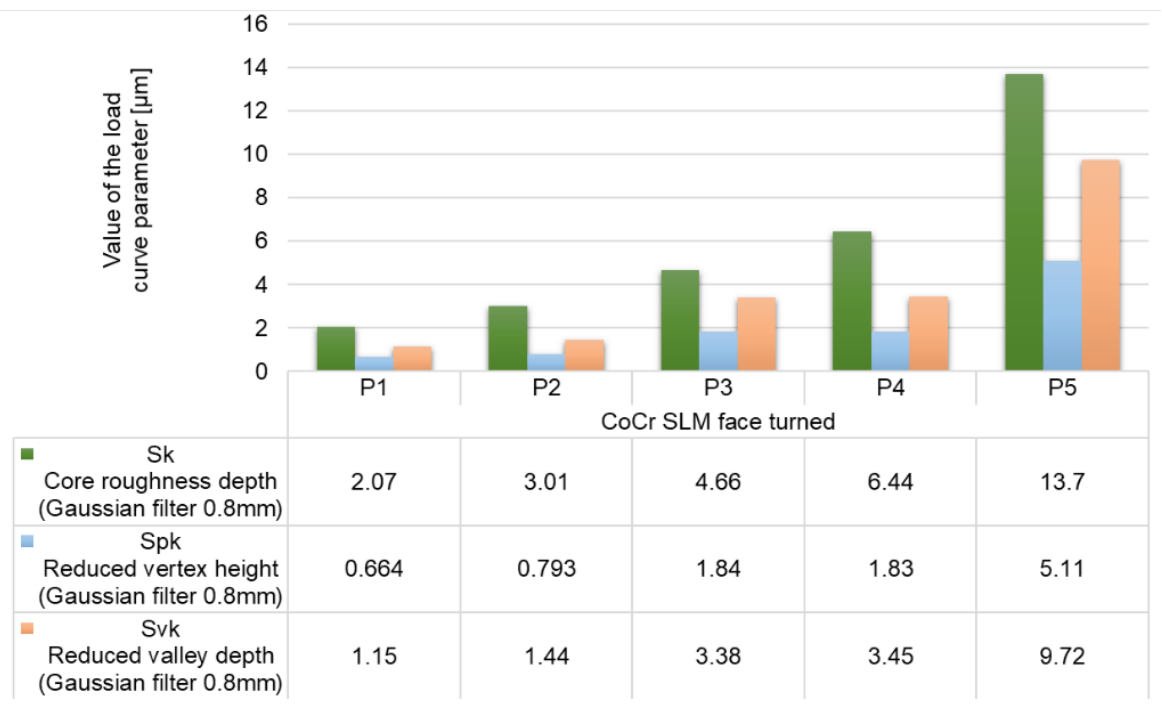

Fig. 2. SGS values of $S k$, $S p k$ and $S v k$ load capacity curve (core width, peak height and depth of surface valleys) after face turning for CoCr materials manufactured in the SLM process

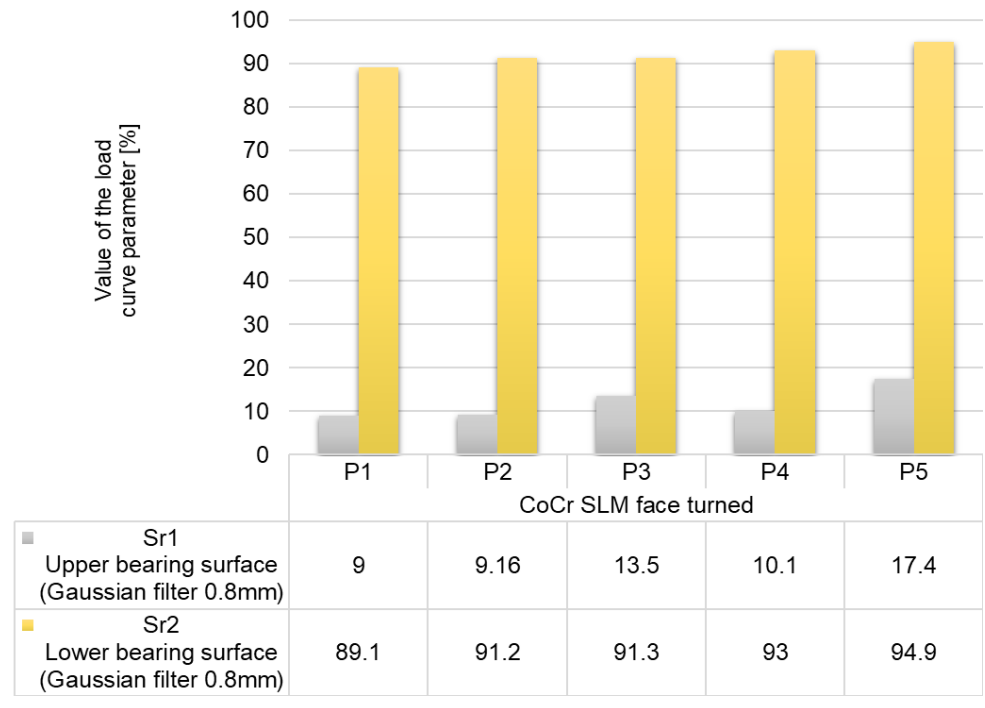

Fig. 3. Values of SGS technological parameters after face turning of CoCr materials produced in the SLM process 
Fig. 3 presents the values of technological parameters: $\operatorname{Sr} 1$ (areas of elevations filled with material) and $S r 2$ (areas of cavities free of the material), classified as spatial roughness parameters. In the analyzed cases, the $\mathrm{Sr} 2$ values do not change significantly with the change in $f n$ and are higher than those obtained for P0 (the maximum difference is 13\%). The phenomena is different with the $\mathrm{Sr} 1$ parameter - its value increases with the increase of $f n$. In all cases, higher values than baseline (P0) were obtained, which is associated with a decrease in surface roughness.

Functional surface analysis was based on two volumetric parameters: $V m$ (volume of surface material) and $V v$ (volume of empty surface space), the values of which are presented in fig. 4. Also, in this case, the analyzed parameters increase with increasing feed speed, compared to P0 values obtained are lower.

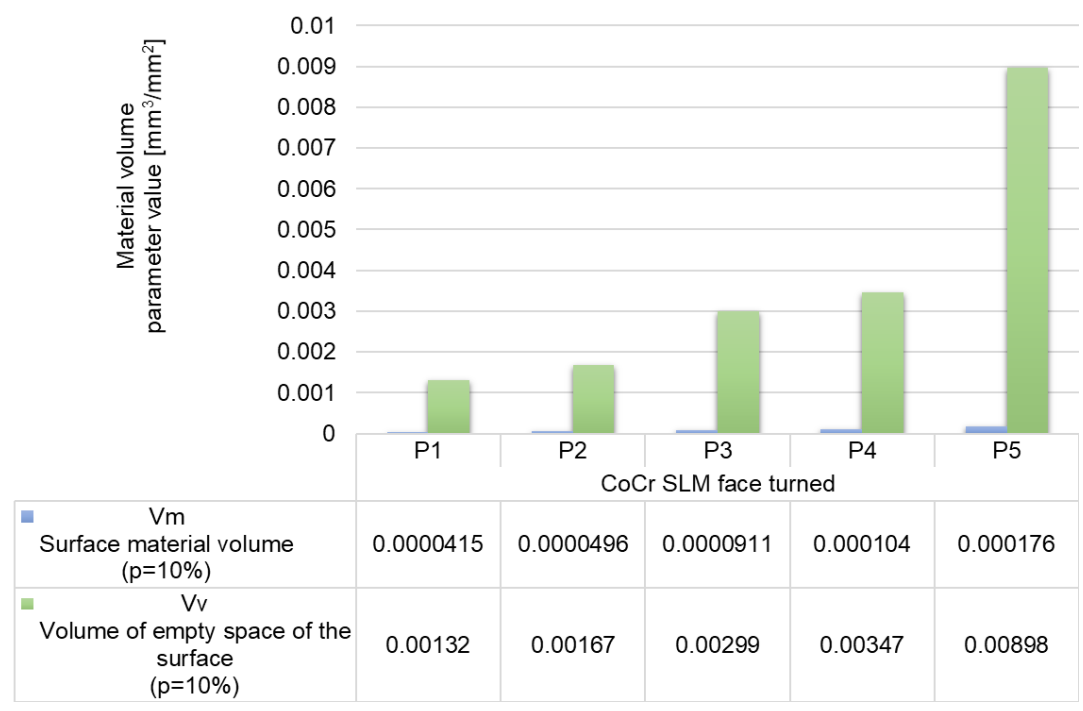

Fig. 4. Values of the material volume parameters after face turning for $\mathrm{CoCr}$ materials produced in the SLM process

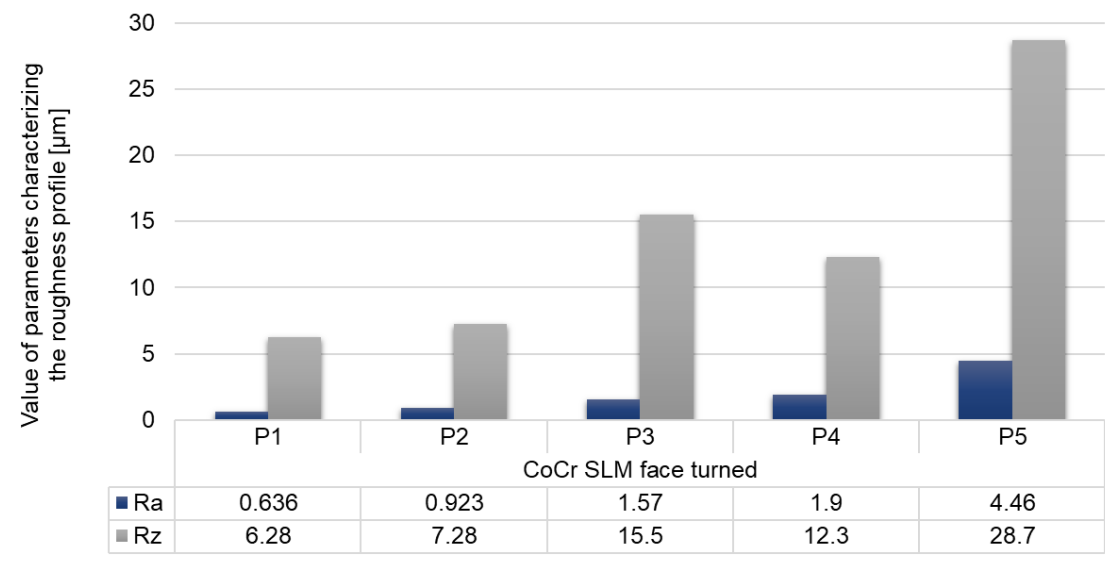

Fig. 5. Characteristic values of the roughness profile $(R a$ and $R z)$ after face turning of CoCr materials manufactured in the SLM process

In figs. 1-5, it can be seen, the correlation between the increase in SGS parameters and the increase in fn. Literature data indicate that it is a feed rate that has the greatest impact on surface quality in the case of machining of CoCr alloys $[9,12]$. The least favorable results were obtained at the highest $f n$ value, which was also the maximum recommended by the manufacturer for the selected tool. 


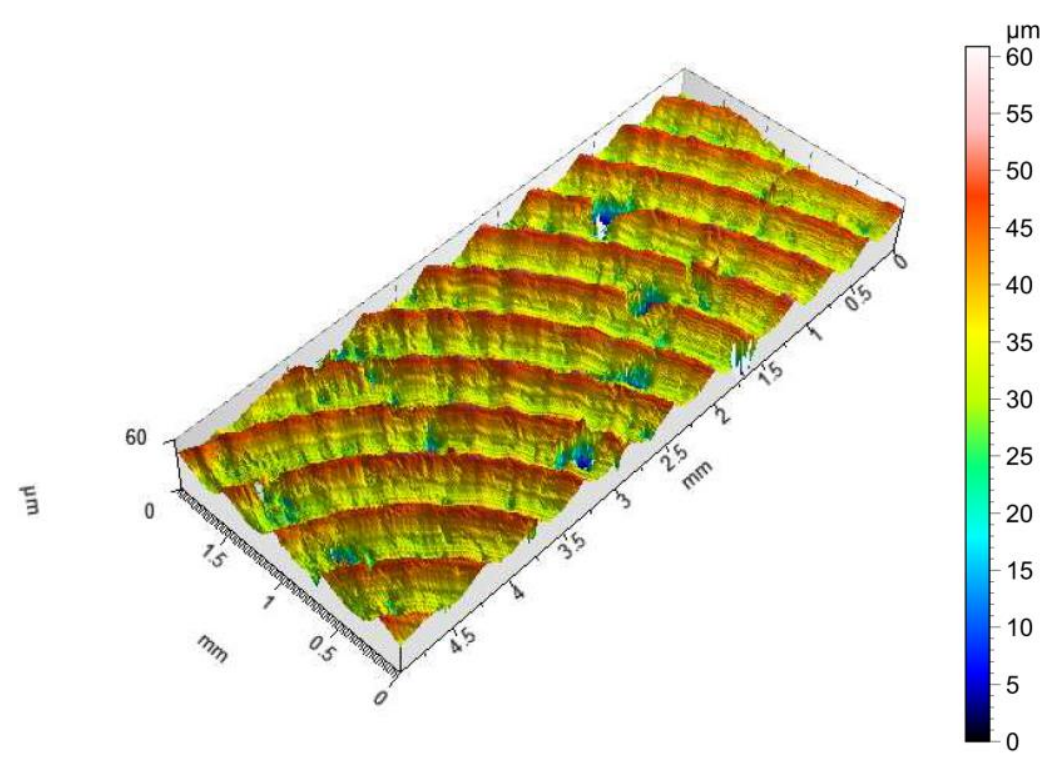

Fig. 6. Surface profiles obtained for selected samples in the sample axis depending on the feed rate $f$ : a) sample P1: $f n=0.10 \mathrm{~mm} / \mathrm{rev}$; b) P5: $f n=0.40 \mathrm{~mm} / \mathrm{rev}$

Based on the analysis of the profiles, it can be seen that at the maximum tested feed rate $(f n=0.4 \mathrm{~mm} / \mathrm{rev})$, cavities are visible on the sample, which may constitute chips due to excessively high $f n$ value. The same has been observed by other researchers $[12,13]$. According to them, adhesive wear and chipping were the dominant wear acting on the tool and faces at high feed rates.

\section{Summary}

SGS tests after face turning of six samples produced by the SLM method CoCr alloy are presented. Values characterizing the height, volume, functional parameters, and roughness profiles were considered. The analysis showed a correlation between the feed rate increase and the obtained values of individual SGS parameters. These studies confirmed that the increase in feed rate negatively affects the surface quality also in the case of materials obtained in the SLM process. However, from a practical point of view, depending on the area of application, it is possible to obtain surfaces with a favorable ratio of deep scratches and small uneven vertices, guaranteeing high biocompatibility, e.g. with bone tissues.

\section{REFERENCES}

[1] Karpuschewski B., Pieper H.J., Krause M., Döring J. "CoCr Is Not the Same: CoCr-blanks for dental machining". Future Trends in Production Engineering. Springer, Berlin, Heidelberg (2013): 261-274, https://doi.org/10.1007/978-3-642-24491-9_26.

[2] Królikowski M., Krawczyk M. „Obróbka skrawaniem oraz techniki przyrostowe jako integralne etapy procesu wytwarzania hybrydowego z metali w Przemyśle 4.0". Mechanik. 8-9 (2018): 769-771, https://doi.org/10.17814/mechanik.2018.8-9.129.

[3] Ahearne E., Baron S. "Fundamental mechanisms in orthogonal cutting of medical grade cobalt chromium alloy (ASTM F75)", CIRP - Journal of Manufacturing Science and Technology. 19 (2017): 1-6, https://doi.org/10.1016/j.cirpj.2017.02.001.

[4] Pasang T., Lees S., Takahashi M., Fujita T., Conor P., Tanaka K., Kamiya O. "Machining of dental Alloys: Evaluating the surface finish of laterally milled Co-Cr-Mo Alloy". Procedia Manufacturing. 13 (2017): 512, https://doi.org/10.1016/j.promfg.2017.09.002.

[5] Shokrani A., Dhokiaa V., Newman S.T. "Cryogenic high speed machining of cobalt chromium alloy". Procedia CIRP. 46 (2016): 404-407, https://doi.org/10.1016/j.procir.2016.04.045.

[6] Axinte D., Guo Y., Liao Z., Shih A. J., M'Saoubi R., Sugita N. "Machining of biocompatible materials - Recent advances", CIRP Annals - ManufacturingTechnology. Available online: 6 June 2019. In press, https://doi.org/10.1016/j.cirp.2019.05.003

[7] Aykut Ş., Bagci E., Kentli A., Yazıcıog lu O. "Experimental observation of tool wear, cutting forces and chip morphology in face milling of cobalt based super-alloy with physical vapour deposition coated and uncoated tool". Materials \& Design. 28, 6 (2007): 1880-1888, https://doi.org/10.1016/j.matdes.2006.04.014. 
[8] Zeng S., Blunt L. "Experimental investigation and analytical modelling of the effects of process parameters on material removal rate for bonnet polishing of cobalt chrome alloy". Precision Engineering. 38, 2 (2014): 348-355, https://doi.org/10.1016/j.precisioneng.2013.11.005.

[9] Zaman H.A., Sharif S., Kim D-W., Idris M.H., Suhaimi M.A., Tumurkhuyag Z. "Machinability of Cobaltbased and Cobalt Chromium Molybdenum Alloys - A Review". Procedia Manufacturing. 11 (2017): 563570, https://doi.org/10.1016/j.promfg.2017.07.150.

[10] PN-EN ISO 25178-2:2012. Specyfikacje geometrii wyrobów (GPS). Struktura geometryczna powierzchni: Przestrzenna -Część 2. Terminy, definicje i parametry struktury geometrycznej powierzchni.

[11] PN-EN ISO 4287:1999/A1:2010 Specyfikacje geometrii wyrobów - Struktura geometryczna powierzchni: metoda profilowa - Terminy, definicje i parametry struktury geometrycznej powierzchni.

[12] Bruschi S., Ghiotti A., Bordin A. "Effect of the process parameters on the machinability characteristics of a CoCrMo Alloy". Key Eng. Mater. 554-557 (2013): 1976-1983, https://doi.org/10.4028/www.scientific.net/KEM.554-557.1976.

[13] Shao H., Li L., Liu L.J., Zhang S.Z. "Study on machinability of a stellite alloy with uncoated and coated carbide tools in turning". J. Manuf. Process. 15, 4 (2013): 673-681, https://doi.org/10.1016/j.jmapro.2013.10.001. 
